\title{
Functional tissue engineering of ligament healing
}

\author{
Shan-Ling Hsu+1,2, Rui Liang ${ }^{\dagger 1}$ and Savio LY Woo*1
}

\begin{abstract}
Ligaments and tendons are dense connective tissues that are important in transmitting forces and facilitate joint articulation in the musculoskeletal system. Their injury frequency is high especially for those that are functional important, like the anterior cruciate ligament (ACL) and medial collateral ligament (MCL) of the knee as well as the glenohumeral ligaments and the rotator cuff tendons of the shoulder. Because the healing responses are different in these ligaments and tendons after injury, the consequences and treatments are tissue- and site-specific. In this review, we will elaborate on the injuries of the knee ligaments as well as using functional tissue engineering (FTE) approaches to improve their healing. Specifically, the ACL of knee has limited capability to heal, and results of non-surgical management of its midsubstance rupture have been poor. Consequently, surgical reconstruction of the ACL is regularly performed to gain knee stability. However, the long-term results are not satisfactory besides the numerous complications accompanied with the surgeries. With the rapid development of FTE, there is a renewed interest in revisiting ACL healing. Approaches such as using growth factors, stem cells and scaffolds have been widely investigated. In this article, the biology of normal and healing ligaments is first reviewed, followed by a discussion on the issues related to the treatment of ACL injuries. Afterwards, current promising FTE methods are presented for the treatment of ligament injuries, including the use of growth factors, gene delivery, and cell therapy with a particular emphasis on the use of ECM bioscaffolds. The challenging areas are listed in the future direction that suggests where collection of energy could be placed in order to restore the injured ligaments and tendons structurally and functionally.
\end{abstract}

\section{Introduction}

Ligaments and tendons are important structures that are designed to transmit forces and facilitate joint articulation in the musculoskeletal system. As such, these tissues are frequently injured during sports and work related activities. In the case when the anterior cruciate ligament (ACL) and medial collateral ligament (MCL) of the knee as well as the glenohumeral ligaments and the rotator cuff tendons of the shoulder are torn, the respective joints can become functionally disabled while the soft tissue in and around the joints including the cartilage, menisci, and others can be predisposed to damage. In severe cases, ligament and tendon injuries can bring on the early symptoms of osteoarthritis.

The healing responses following injuries to different ligaments and the consequences can vary greatly. The ACL of knee has limited capability to heal, and the results of nonsurgical management of its midsubstance rupture have

\footnotetext{
*Correspondence: ddecenzo@pitt.edu

1 Musculoskeletal Research Center, Department of Bioengineering, Swanson School of Engineering, University of Pittsburgh, Pittsburgh, PA, USA + Contributed equally

Full list of author information is available at the end of the article
}

been poor[1,2]. Consequently, surgical reconstruction of the ACL using tissue autografts, such as the bone-patellar tendon-bone (BPTB) or hamstrings tendon (HTs), and soft tissue allografts is regularly performed to gain knee stability. However, there are complications coming with these reconstruction surgeries that include the donor site morbidity, extensor deficit of the knee, degeneration of tissue replacement graft, hamstring muscle weakness, bone tunnel enlargement and other side effects[3-12]. In spite of significant efforts being made to improve the surgical procedures for ACL reconstruction during the last twenty years, many patients still develop osteoarthritis early in the long term $[13,14]$.

Extra-articular ligaments such as the MCL of the knee have a high propensity for healing without surgical management[15-20]. Their structural properties based on tensile testing of the femur-MCL-tibia complex (FMTC), can be restored within weeks, and as a result, patients can return to work and sports quickly with functional treatment using splints or braces. Nevertheless, laboratory studies has discovered that the mechanical properties, histomorphological appearance, and biochemical composition of these healed MCL remain poor when compared 
to those of the normal MCL[18,21-25]. With the availability of functional tissue engineering (FTE) and the promising use of growth factors, stem cells, and bioscaffolds, research work to improve the tissue quality has been done, especially by means of good animal models such as the rabbit, dog and goat[26]. Much has been learnt about the healing process as well as the potential for extending the novel methods to the healing of other ligaments and tendons including the ACL. Consequently, there is a renewed interest in revisiting ACL healing in order to avoid some of the complications resulted from surgical reconstruction.

In this article, we will first briefly review the biology of normal and healing ligaments and tendons, and then focus on the issues related to the treatment of ACL injuries. Afterwards, we move on to the presentation of promising FTE methods for the treatment of ligament injuries, including the use of growth factors, gene delivery, and cell therapy, but a particular emphasis will be placed on the use of ECM bioscaffolds. To conclude, we will outline some challenging areas and suggest where we should put our energy in order to closely restore the structure and function of injured ligaments and tendons to their pre-injury levels.

\section{Normal and Healing Ligaments and Tendons}

Ligaments and tendons are dense connective tissue that connect bone to bone and bone to muscle, respectively. These tissues are relatively hypocellular, as well as hypovascular[27-30]. Collagen fibers are the primary matrix structure, and approximately $70 \%$ to $80 \%$ of the dry weight of normal tendon or ligament is composed of type I collagen, which is primarily responsible for the stiffness and strength of these tissues. The collagen fibrils that are subunits of collagen fibers are surrounded by extrafibrillar matrix, such as water (65\% to $70 \%$ of the total weight), elastin (5\% to $7 \%$ of the dry weight), proteoglycans, and glycolipids[31,32]. Fibroblasts are the predominant cell type and are arranged in rows between bundles of parallel arranged collagen fibrils (Fig. 1). There are also minor types of collagen, including types III, V, X, XI, and XII[3336]. Type III collagen is responsible for ligament and tendon repair [35] whereas type $\mathrm{V}$ collagen is believed to exist in association with type I collagen to regulate the collagen fibril diameter[37,38]. Other collagens such as types XII and XIV, called fibril-associated collagens with interrupted triple helices (FACITs), are localized to the surface of the fibrils[34]. Type XII collagen is thought to provide specific bridges between fibrils and other matrix components, such as decorin and fibromodulin[36] while type XIV collagen is involved in linear fibril growth[39]. Other molecules involved in collagen fibril assembly are a group of small leucine-rich proteoglycans (SLRPs), such as decorin, lumican, biglycan, and fibromodulin[37,40-
44]. On the other hand, even though the morphological appearances of ligaments and tendons are similar to each other, there are substantial and important differences in terms of their biochemistry, hence their biomechanical properties[30,45-47].

Generally, ligaments and tendons are metabolically active with incessant cell renewal and matrix turnover albeit at a relatively slow rate[47]. Therefore, after injury, ligaments and tendons heal at a slower rate than most other soft tissue because of their hypovasculariy as well as hypocellularity. Further, their environment would have profound effects on their healing capabilities. For extra-articular ligaments, such as the MCL, the healing is spontaneous and classical. It can be divided into 4 overlapping phases: Phase I is featured by initial bleeding and blood filled into the gap with hemostasis during the initial 72 hours. A hematoma is developed to bridge the torn ends. This area is then infiltrated by inflammatory cells including monocytes, leukocytes, and macrophages that secrete cytokines and growth factors to start the healing process. Phase II, the cellular proliferation phase, is featured by inflammation reaction and granulation tissue formation with the arrival of fibroblasts that slowly populate the injured area and synthesize type III collagen and, to a lesser extent, type I collagen. Phase III has cell proliferation and matrix deposition forming a vascular neo-ligament, while phase IV is featured by the organization of collagenous tissue to be arranged along the functional axis of the ligament as well as synthesis of higher proportion of type I collagen and then long-term remodeling[21].

Investigators have discovered that various cytokines are produced by the infiltrating cells. These endogenous growth factors such as platelet-derived growth factor (PDGF) and transforming growth factor beta (TGF- $\beta$ ) are present in high concentrations during Phase I and II. Studies found that after the initial surge, the level of growth factors started to decrease to baseline level from 2 to 3 weeks of healing $[48,49]$. Such temporal growth factor responses at the initial phases of ligament healing are critical for the filling of tissue defect with neo-tissue and thereafter the restoration of function.

Knowledge on the mechanisms of ligamentous tissue healing has been accruing rapidly through intense studies, which will no doubt benefit the treatment of injured ligaments through properly designed functional tissue engineering approaches.

\section{Issues Relating to Healing of the Anterior Cruciate Ligament (ACL)}

In the case of the ACL, however, the manner of its healing is entirely different from those described above. Following injury, the thin synovial sheath of ACL is disrupted, and blood dissipates in the synovial fluid, making the for- 


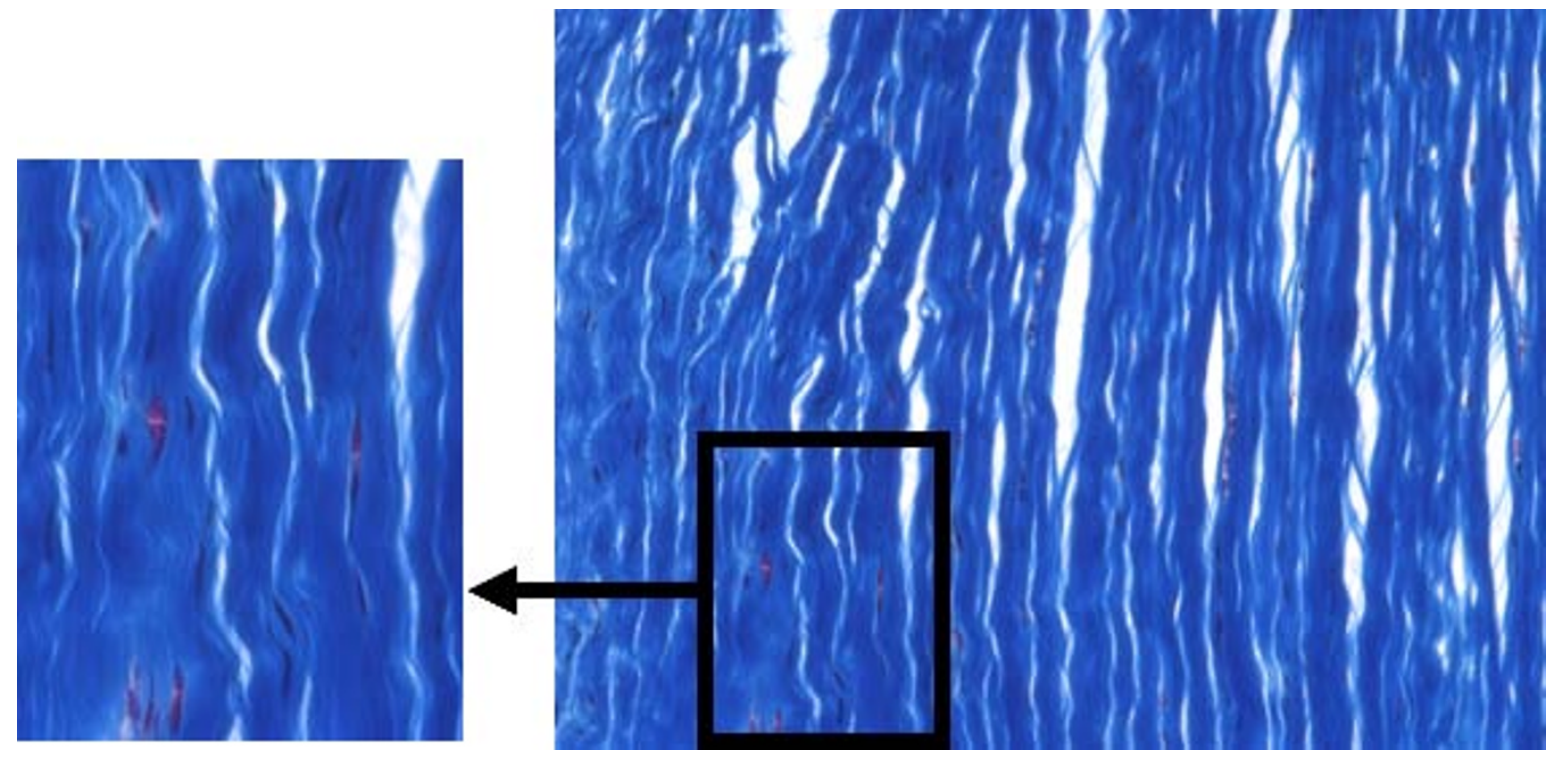

Figure 1 Histological image of rabbit medial collateral ligament showing highly organized collagen fibers and the spindle shaped fibroblasts (Masson's Trichrome staining at a magnification of $200 \times$ ).

mation of a localized hematoma difficult. With such a lack of supply of cytokines and growth factors and a low supply of reparative cells at the injury site, the ability for a torn ACL to heal becomes limited[50-52]. In addition, its torn ends retract significantly because of the high residual strain existed in the intact ACL, making the bridging of the gap even more difficult[52]. Biologically, it is also found that the properties of ACL fibroblasts are different from those derived from other ligaments. They have comparatively low mobility, low proliferation and metabolic activities as well as low matrix production tendencies[53-55]. The cells actually further exhibit higher matrix metalloproteinases (MMPs) activities and poor adhesive strength[56,57]. With all these factors added to the local environmental constraints, the intra-articular ACL rupture, especially at midsubstance, failed to heal on its own.

Clinically, primary repair of ACL using sutures began with A.W. Mayo in 1903 and then followed by O'Donoghue, Feagin, and many others[58-61]. Overall, the results had not been encouraging as they were not different from conservative treatment[59,62-67]. As much as $70 \%$ of the patients had knee instability[59,65,67]. Therefore, ACL reconstruction using autografts and allografts has become popular for a treatment. It is estimated that over $100,000 \mathrm{ACL}$ reconstructions are performed in the United States annually with the majority of which using either hamstrings or bone-patellar tendon-bone autografts[68-73]. Although the use of the latter offers the advantage of direct bone to bone fixation for better initial knee stability, the associated problems such as donor site morbidity, knee pain, extensor deficit, and other side effects have led many surgeons to use the hamstrings autograft[10,66,74-80]. Nevertheless, there are problems associated with bone-soft tissue healing, less knee stability, tunnel enlargement, graft motion in the bone tunnels, etc.[9-11,14]. In either case, many patients had good knee stability and after a period of rehabilitation following surgery, they could return to work or sports. However, in the long term, $20-25 \%$ of the patients showed less than satisfactory results with some progressing to knee osteoarthritis[81-87].

\section{Functional Tissue Engineering for ACL Healing}

More recently, efforts have begun to focus on alternative approaches that can avoid the problems that associated with ACL reconstruction. A healed ACL has many advantages including the preservation of its native insertion sites as well as its proprioceptive function. Clinical techniques like the 'healing response' by making microfracture holes in the femur close to the ACL insertion was pioneered by Steadman. It aims to introduce blood clot to the injured ACL encouraging hematoma formation and bring in more reparative cells to heal the torn $\mathrm{ACL}[51,88,89]$. For patients over 40 years of age that have proximal ACL tears, this procedure has successful results[88]. On the other hand, there are also experimental evidences showing that a transected ACL might heal 
with exogenous aids, such as the supplementation of growth factors or use of a scaffold[90-94]. It has been shown that the ACL cells can proliferate and make matrix following FTE treatment $[95,96]$.

FTE is a new field that combines morphology, molecular biology, biochemistry, biomechanics, and other areas. For ligaments, it is particularly important to consider their functional roles in the design and development of novel FTE approaches including the use of growth factors, gene transfer/gene therapy, cell therapy, and extracellular matrix bioscaffolds. Specifically, besides the encouragement for cell proliferation and matrix production, the unique characteristics of the dense regular connective tissue, the natural anatomical insertions to the bones as well as the structural and mechanical properties that are critical for the function of ligaments to sustain and transfer loads, should also be the targets of an optimal FTE treatment. Previous works had reported the use of hyaluronic acid (HA), basic fibroblast growth factor (bFGF), collagen-platelet rich plasma (C-PRP) as well as stem cells to heal the central ACL defects[90-94], and all have shown an increased vascularization, increased tissue formation as well as improvements in some of the biomechanical properties. The following is a brief review of more recent available approaches aiding in the healing of ACL in the laboratory. These methods are the major biological augmentations used in the field of tissue engineering.

\section{Growth factors}

Due to their important physical functions in the regulation of cell responses to injury, the use of growth factors can be advantageous to heal injured ligaments. In the literature, different growth factors such as FGF, TGF- $\beta$, PDGF, epidermal growth factor (EGF), insulin-like growth factor (IGF), growth and differentiation factor (GDF) and nerve growth factor (NGF) have been shown to improve vascularization and new tissue formation that resulted in improved structural properties of ligamentbone complex[97-101]. These growth factors also exhibited positive effects on improving ACL healing. In an ACL central defect model in dogs, the bFGF pallets caused healing tissue formation with increased vascularity at early stage compared to little or no tissue formation in the control[94]. In addition, the application of PRP, which contains increased presence of various growth factors, was also reported. It was found that the collagenPRP complex could significantly increase the tissue formation of an ACL central defect in a canine model and enhance the structural properties of the femur-ACL-tibia complex (FATC) of a completely transected ACL after primary repair in a porcine model[92,102,103]. The potential of synergistic effects of two or more growth factors has also been explored. A combination of PDGF$\mathrm{BB} / \mathrm{TGF}-\beta 1$ did not enhance the structural properties of the healing FMTC compared to the use of PDGF-BB alone[104]. Clearly, the healing process of ligaments is much more complex than simply supplementing certain growth factors. Considering the milieu around the healing tissue differs in location and changes with time, strategies of treatment could be more specific. Further, growth factors have short half-lives, which have limited their efficacy. Therefore, safe and reproducible delivery systems that would allow sustained delivery of growth factors to the injury site need to be vigorously investigated[105-107]. Potential of using synthetic PLGA microspheres, fibrin-heparin delivery system, and metallic porous materials and so on as well as refinement of these systems are being investigated[108].

\section{Gene transfer/Therapy}

Gene transfer using carriers including both retroviral and adenoviral vectors as well as liposomes have been used to induce DNA fragments into healing ligaments by promoting or depressing the expression of certain genes[109]. An in situ gene transfer of TGF- $\beta 1$ using an adenoviral vector in a collagen hydrogel placed between the stumps of a ruptured ACL resulted in an increase in the cellularity and the deposition of type III collagen[110]. Similarly, transfer of IGF-1 cDNA by using an adenovirus vector led to the synthesis and deposition of increased amounts of types I and III collagen, elastin, tenascin, and vimentin in the same model[111]; thus confirming the potential of using vector-laden hydrogels for the in situ delivery of genes to damaged ligaments for potential biological repair of the ACL.

\section{Cell therapy}

Mesenchymal progenitor cells (MPCs) and mesenchymal stem cells (MSCs) have shown tremendous potential in tissue engineering $[112,113]$. MSCs isolated from a variety of adult tissues including the bone marrow (BM) have the capacity to differentiate into different cell types and therefore are attractive to be used as a potential therapeutic tool for tissue repair. In our research center, it was found that MSCs implanted in the injured rat MCL differentiated into fibroblasts[114]. Further, when an MSCseeded implant was delivered to an Achilles tendon with $1 \mathrm{~cm}$ gap injury, the healing tissue was grown with a significantly larger cross-sectional area, and the collagen fibers appeared to be better aligned than those in the controls[115]. Similarly, an autologous MSC collagen graft could accelerate the healing as well as improve the quality of healing tissue of patellar tendon in rabbits[116]. Knowing these positive findings, an intra-articular injection of bone marrow derived mysenchymal cells in a rat model with partially transected ACL was done and the formation of healing tissue was found. Consequently, the ultimate failure load of FATC was increased when compared 
to non-treated control[117]. These results are encouraging because the MSCs have the potential to serve as a vehicle for delivering therapeutic molecules as well as directly enhance the healing of ligaments.

Although it is an appealing property that the MPC/MSCs have the potential to differentiate into many kinds of cell types, how to differentiate these multi-pluropotent cells into a desired specific cell type are still under investigation. Thus, research in the field presents new challenging opportunities in developing novel techniques for optimizing the stem cell system as well as their application in the regeneration of ACL.

\section{Extracellular matrix bioscaffolds}

Bioscaffolds derived from extracellular matrix (ECM), such as the porcine small intestinal submucosa (SIS) and urinary bladder membrane (UBM), have been found to support tissue regeneration and repair of ligaments and tendons[118-129]. SIS is mainly composed of collagen (90\% of dry weight) and contains cytokines and growth factors such as FGF and TGF- $\beta[130,131]$. It is a resorbable bioscaffold that can provide a collagenous structure for the healing cells to reside as well as hold nutrients necessary for healing[118].

We have applied the SIS bioscaffold to treat a central third defect of patellar tendon in a rabbit model, which is commonly the donor site of autografts for ACL reconstruction. It was found that the bioscaffold could encourage neo-tissue formation in the defect and consequently, the structural properties of the bone-patellar tendonbone construct were significantly improved[132]. Further, with a single layer of SIS applied to a $6 \mathrm{~mm}$ gap injury of the rabbit MCL, the quality of the healing tissue was significantly improved. The morphology showed aligned collagen fibers, while the gene expressions of the fibrillogenesis-related molecules such as collagen $\mathrm{V}$ and some SLRPs were down-regulated with concomitant increases in the collagen fibril diameters (Fig. 2). Correspondingly, the tangent modulus and the stress at failure of the healing MCL were increased by about 50\%[123-126].

With these successes, we have used the SIS bioscaffolds for ACL healing. Using a goat stifle joint as a model, we combined the SIS bioscaffold with SIS hydrogel to heal a transected ACL following primary repair[133]. After 12 weeks, the gap was filled with continuity of neo-tissue formation with a similar cross-sectional area and shape as the sham-operated ACL. The neo-tissues were slightly reddish in color and less opaque than the sham-operated control ACLs which indicated that the fibers in the neotissue was still not as dense (Fig. 3). Histologically, the collagen fibers were aligned with spindle shaped fibroblasts at 12 weeks. Functional measurements on knee kinematics and in-situ forces were done using a novel robotic/universal force-moment sensor (UFS) testing system developed in our research center[25,134,135]. When an external $67 \mathrm{~N}$ anterior-posterior (A-P) tibial load was applied to the stifle joint at flexion angles of knee $30^{\circ}, 60^{\circ}$, and $90^{\circ}$, the resulting A-P joint instability in the ECMtreated group were significantly reduced to $63 \%, 49 \%$, and $47 \%$ of those for the ACL-deficient joints, respectively. Meanwhile, in-situ forces of the neo-ACL were similar to those of the intact ACL. Together, these data suggest that the ECM treated healing ACLs could contribute positively to knee function. Uniaxial testing of the FATC also showed that the tensile stiffness of the ECM-treated ACL reached $42 \%$ of the normal ACL at 12 weeks post-surgery, which was comparable to the results of ACL reconstruction. These findings indicate that the application of ECM bioscaffolds plus ECM hydrogel should have the potential to be a good candidate tool for ACL healing.

\section{Future directions}

Research to enhance ligamentous tissue healing and regeneration has reached an exciting time as new developments on both biological and biomechanical augmentation can be used to improve their outcome. With
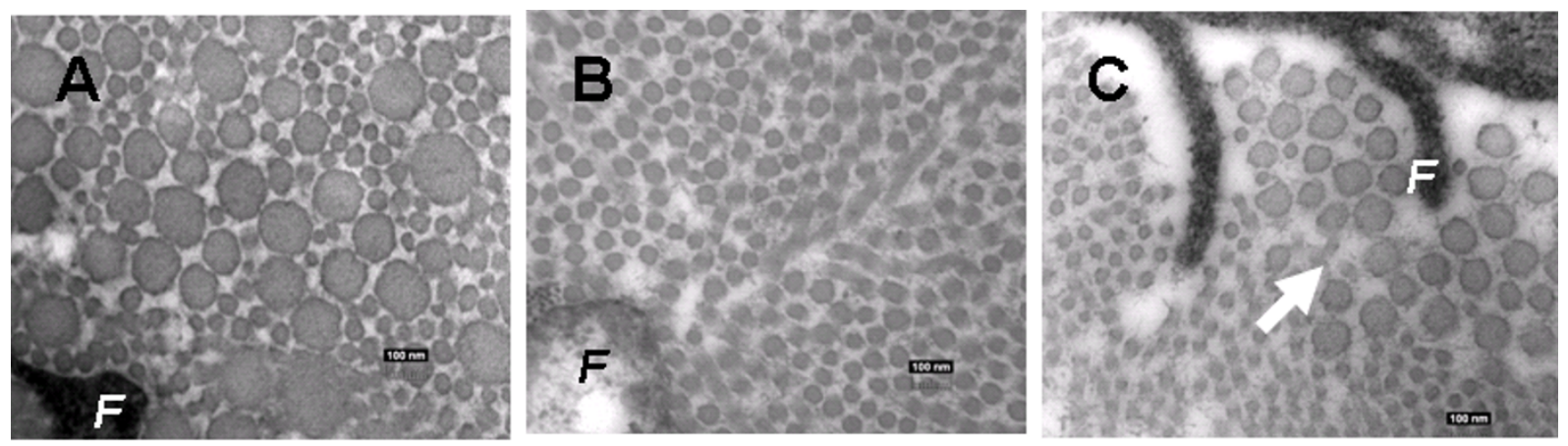

Figure 2 Transmission electron microscopy images of cross sectional view of collagen fibrils in (A) Normal MCL; (B) Healing MCL at 6 weeks; and (C) SIS-treated healing MCL at 6 weeks. F indicates fibroblasts. Arrow points to the large newly formed collagen fibrils. 
A. Sham-operated ACL

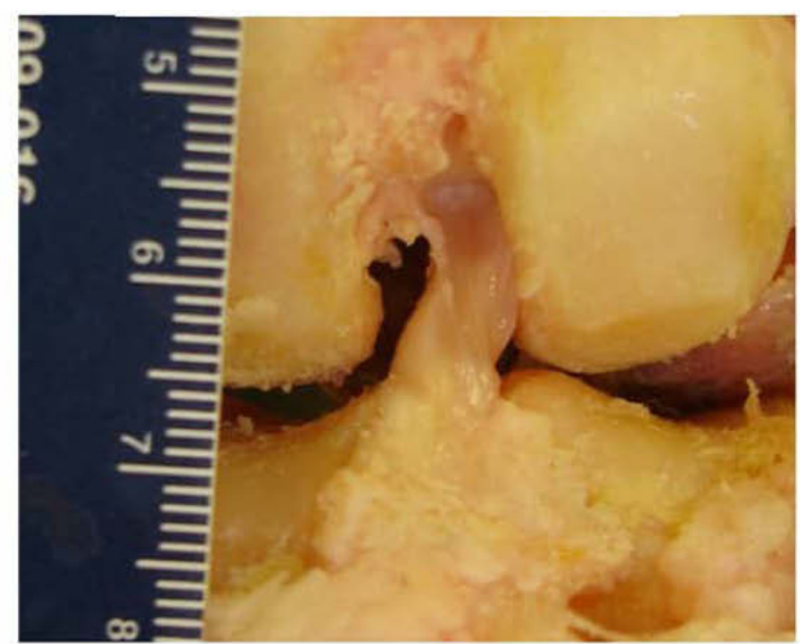

\section{B. ECM-treated healing ACL}

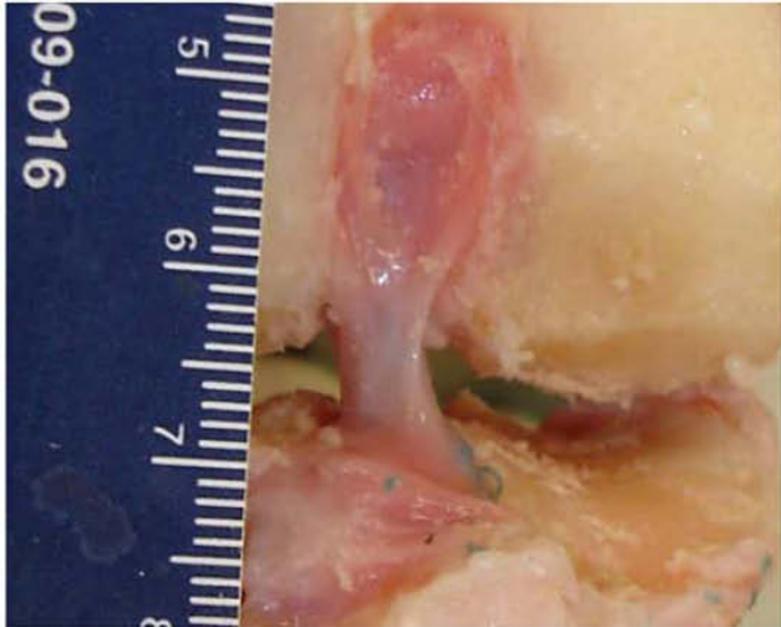

Figure 3 Gross morphology of (A) Sham-operated ACL; and (B) ECM-treated healing ACL at 12 weeks (permission requested from Woo et al. [133]).

functional tissue engineering, the ECM bioscaffolds could be further improved via mechanical stimuli and cell seeding to alter their ultrastructure to be closer to that of the highly aligned collagen fiber network of native ligaments [136-139]. Another area for future studies will involve the use of the ECM bioscaffolds derived from genetically modified pigs, such as those with the galactose $\alpha 1,3$-galactose ( $\alpha \mathrm{Gal}$ ) deficiency, to reduce hyperacute rejection of the xenograft in humans[140]. With the reduction or elimination of the immunogenicity from the ECM bioscaffolds, its usage will be more widely acceptable [141-144].

Studies should also be done to control the release of growth factor. New delivery system will be needed such that the sustained release of growth factors could stimulate the healing process over time in order to mimic the expression of growth factors in vivo that last long time after tissue injury.

Finally, there is another class of scaffolds that will be available in the field, i.e., biodegradable metallic materials such as porous magnesium or magnesium oxide, that have the potential to facilitate ligament and tendon healing and regeneration[145-147]. The advantages of these "smart" scaffolds include their initial stiffness and controllable degradation rate as they are replaced by the neotissue formation. It is also possible to protein-coat these metals for better tissue integration and control release of growth factors and cytokines to sustain tissue healing as well as to guide tissue regeneration.

\section{Conclusions}

Clearly, much work remains but there are exciting possibilities. All will require much interdisciplinary and multidisciplinary research. We believe that when biologists, biochemists, clinicians, and bioengineers are teaming together with other experts, it will be possible to make positive advances on ligament and tendon regeneration. In the end, more complete recovery of these tissues will allow patients to resume their daily activities as well as sports.

\section{Competing interests}

The authors declare that they have no competing interests.

\section{Authors' contributions}

SH, RL and SLYW participated in the review design, literature search, coordination and drafting the manuscript. All authors read and approved the final manuscript.

\section{Acknowledgements}

Financial support for the cited studies performed in the our research center was provided by the National Institute of Health Grants AR41820 and AR39683, National Science Foundation/Engineering Research Centers (NSF/ERC) award, as well as funding from Commonwealth of Pennsylvania through McGowan Institute for Regenerative Medicine.

\section{Author Details}

1Musculoskeletal Research Center, Department of Bioengineering, Swanson School of Engineering, University of Pittsburgh, Pittsburgh, PA, USA and 2Department of Orthopaedic Surgery, Chang Gung Memorial Hospital Kaohsiung Medical Center, Chang Gung University College of Medicine, Kaohsiung, Taiwan

Received: 18 February 2010 Accepted: 21 May 2010 Published: 21 May 2010 


\section{References}

1. Andersson AC: Knee laxity and function after conservative treatment of anterior cruciate ligament injuries. A prospective study. Int J Sports Med 1993, 14(3):150-153.

2. Meunier A, Odensten M, Good L: Long-term results after primary repair or non-surgical treatment of anterior cruciate ligament rupture: a randomized study with a 15-year follow-up. Scand J Med Sci Sports 2007, 17(3):230-237.

3. Aune AK, Holm I, Risberg MA, Jensen HK, Steen H: Four-strand hamstring tendon autograft compared with patellar tendon-bone autograft for anterior cruciate ligament reconstruction. A randomized study with two-year follow-up. Am J Sports Med 2001, 29(6):722-728.

4. Marder RA: Arthroscopic-assisted reconstruction of the anterior cruciate ligament. West J Med 1991, 155(2):172.

5. Kartus J, Magnusson L, Stener S, Brandsson S, Eriksson Bl, Karlsson J: Complications following arthroscopic anterior cruciate ligament reconstruction. A 2-5-year follow-up of 604 patients with special emphasis on anterior knee pain. Knee Surg Sports Traumatol Arthrosc 1999, 7(1):2-8

6. Paulos LE, Rosenberg TD, Drawbert J, Manning J, Abbott P: Infrapatella contracture syndrome. An unrecognized cause of knee stiffness with patella entrapment and patella infera. Am J Sports Med 1987, 15(4):331-341.

7. Sachs RA, Daniel DM, Stone ML, Garfein RF: Patellofemoral problems after anterior cruciate ligament reconstruction. Am J Sports Med 1989, 17(6):760-765

8. Shelbourne KD, Wilckens JH, Mollabashy A, DeCarlo M: Arthrofibrosis in acute anterior cruciate ligament reconstruction. The effect of timing of reconstruction and rehabilitation. Am J Sports Med 1991, 19(4):332-336.

9. Clatworthy MG, Annear P, Bulow JU, Bartlett RJ: Tunnel widening in anterior cruciate ligament reconstruction: a prospective evaluation of hamstring and patella tendon grafts. Knee Surg Sports Traumatol Arthrosc 1999, 7(3):138-145.

10. Feller JA, Webster KE: A randomized comparison of patellar tendon and hamstring tendon anterior cruciate ligament reconstruction. Am J Sports Med 2003, 31(4):564-573.

11. Jansson KA, Harilainen A, Sandelin J, Karjalainen PT, Aronen HJ: Bone tunnel enlargement after anterior cruciate ligament reconstruction with the hamstring autograft and endobutton fixation technique. A clinical, radiographic and magnetic resonance imaging study with 2 years follow-up. Knee Surg Sports Traumatol Arthrosc 1999, 7(5):290-295

12. Nebelung W, Becker R, Merkel M, Ropke M: Bone tunnel enlargement after anterior cruciate ligament reconstruction with semitendinosus tendon using Endobutton fixation on the femoral side. Arthroscopy 1998, 14(8):810-815.

13. Keays SL, Bullock-Saxton JE, Keays AC, Newcombe PA, Bullock MI: A 6-year follow-up of the effect of graft site on strength, stability, range of motion, function, and joint degeneration after anterior cruciate ligament reconstruction: patellar tendon versus semitendinosus and Gracilis tendon graft. Am J Sports Med 2007, 35(5):729-739.

14. Pinczewski LA, Lyman J, Salmon LJ, Russell VJ, Roe J, Linklater J: A 10-year comparison of anterior cruciate ligament reconstructions with hamstring tendon and patellar tendon autograft: a controlled, prospective trial. Am J Sports Med 2007, 35(4):564-574

15. Indelicato PA: Non-operative treatment of complete tears of the medial collateral ligament of the knee. J Bone Joint Surg Am 1983, 65(3):323-329

16. Jokl P, Kaplan N, Stovell P, Keggi K: Non-operative treatment of severe injuries to the medial and anterior cruciate ligaments of the knee. Bone Joint Surg Am 1984, 66(5):741-744.

17. Kannus P: Long-term results of conservatively treated medial collateral ligament injuries of the knee joint. Clin Orthop Relat Res 1988:103-112.

18. Scheffler SU, Clineff TD, Papageorgiou CD, Debski RE, Benjamin C, Woo SL: Structure and function of the healing medial collateral ligament in a goat model. Ann Biomed Eng 2001, 29(2):173-180.

19. Woo SL, Inoue M, McGurk-Burleson E, Gomez MA: Treatment of the medial collateral ligament injury. II: Structure and function of canine knees in response to differing treatment regimens. Am J Sports Med 1987, 15(1):22-29.

20. Weiss JA, Woo SL, Ohland KJ, Horibe S, Newton PO: Evaluation of a new injury model to study medial collateral ligament healing: primary repair versus nonoperative treatment. Journal of Orthopaedic Research 1991, 9(4):516-528.

21. Frank C, Woo SL, Amiel D, Harwood F, Gomez M, Akeson W: Medial collateral ligament healing. A multidisciplinary assessment in rabbits. Am J Sports Med 1983, 11(6):379-389.

22. Frank C, McDonald D, Bray D, Bray R, Rangayyan R, Chimich D, Shrive N: Collagen fibril diameters in the healing adult rabbit medial collateral ligament. Connective Tissue Research 1992, 27(4):251-263

23. Frank C, McDonald D, Shrive N: Collagen fibril diameters in the rabbit medial collateral ligament scar: a longer term assessment. Connective Tissue Research 1997, 36(3):261-269.

24. Niyibizi C, Kavalkovich K, Yamaji T, Woo SL: Type V collagen is increased during rabbit medial collateral ligament healing. Knee Surg Sports Traumatol Arthrosc 2000, 8(5):281-285.

25. Abramowitch SD, Papageorgiou CD, Debski RE, Clineff TD, Woo SL: A biomechanical and histological evaluation of the structure and function of the healing medial collateral ligament in a goat model. Knee Surg Sports Traumatol Arthrosc 2003, 11(3):155-162.

26. Auer JA, Goodship A, Arnoczky S, Pearce S, Price J, Claes L, von Rechenberg B, Hofmann-Amtenbrinck M, Schneider E, Muller-Terpitz R, Thiele F, Rippe KP, Grainger DW: Refining animal models in fracture research: seeking consensus in optimising both animal welfare and scientific validity for appropriate biomedical use. BMC Musculoskelet Disord 2007, 8:72.

27. Bray RC, Rangayyan RM, Frank CB: Normal and healing ligament vascularity: a quantitative histological assessment in the adult rabbit medial collateral ligament. Journal of Anatomy 1996, 188(Pt 1):87-95.

28. Lo IK, Ou Y, Rattner JP, Hart DA, Marchuk LL, Frank CB, Rattner J: The cellular networks of normal ovine medial collateral and anterior cruciate ligaments are not accurately recapitulated in scar tissue. $J$ Anat 2002, 200(Pt 3):283-296.

29. Tozer S, Duprez D: Tendon and ligament: development, repair and disease. Birth Defects Res C Embryo Today 2005, 75(3):226-236.

30. Woo S, An K-N, Frank C, Livesay G, Ma C, Zeminski J, American Academy of Orthopaedic Surgeons: Anatomy, Biology and Biomechanics of Tendon and Ligaments. In Orthopaedic basic science: biology and biomechanics of the musculoskeletal system Edited by: Einhorn TA, Simon SR. Rosemont, III.: American Academy of Orthopaedic Surgeons; 2000:581-616.

31. Bray RC, Salo PT, Lo IK, Ackermann P, Rattner JB, Hart DA: Normal ligament structure, physiology and function. Sports Medicine and Arthroscopy Review 2005, 13(3):127-135.

32. Frank CB: Ligament structure, physiology and function. J Musculoskelet Neuronal Interact 2004, 4(2):199-201.

33. Niyibizi C, Visconti CS, Kavalkovich K, Woo SL: Collagens in an adult bovine medial collateral ligament: immunofluorescence localization by confocal microscopy reveals that type XIV collagen predominates at the ligament-bone junction. Matrix Biol 1995, 14(9):743-751.

34. Walchli C, Koch M, Chiquet M, Odermatt BF, Trueb B: Tissue-specific expression of the fibril-associated collagens XII and XIV. J Cell Sci 1994, 107(Pt 2):669-681.

35. Liu SH, Yang RS, al-Shaikh R, Lane JM: Collagen in tendon, ligament, and bone healing. A current review. Clin Orthop Relat Res 1995, 318:265-278.

36. Font $B$, Eichenberger D, Rosenberg LM, Rest M van der: Characterization of the interactions of type XII collagen with two small proteoglycans from fetal bovine tendon, decorin and fibromodulin. Matrix Biol 1996, 15(5):341-348.

37. Birk DE, Mayne R: Localization of collagen types I, III and V during tendon development. Changes in collagen types I and III are correlated with changes in fibril diameter. European Journal of Cell Biology. European Journal of Cell Biology 1997, 72(4):352-361.

38. Linsenmayer TF, Gibney E, Igoe F, Gordon MK, Fitch JM, Fessler LI, Birk DE: Type $V$ collagen: molecular structure and fibrillar organization of the chicken alpha $1(\mathrm{~V}) \mathrm{NH}$-terminal domain, a putative regulator of corneal fibrillogenesis. J Cell Biol 1993, 121(5):1181-1189.

39. Ruehl M, Erben U, Schuppan D, Wagner C, Zeller A, Freise C, Al-Hasani H, Loesekann M, Notter M, Wittig BM, Zeitz M, Dieterich W, Somasundaram $R$ : The elongated first fibronectin type III domain of collagen XIV is an inducer of quiescence and differentiation in fibroblasts and preadipocytes. J Biol Chem 2005, 280(46):38537-38543.

40. Hakkinen H, Strassburger S, Kahari VM, Scott PG, Eichstetter I, Lozzo RV Larjava $\mathrm{H}$ : A role for decorin in the structural organization of periodontal ligament. Lab Invest 2000, 80(12):1869-1880. 
41. Iozzo RV: The family of the small leucine-rich proteoglycans: key regulators of matrix assembly and cellular growth. Crit Rev Biochem Mol Biol 1997, 32(2):141-174

42. Liu X, Wu H, Byrne M, Krane S, Jaenisch R: Type Ill collagen is crucial for collagen I fibrillogenesis and for normal cardiovascular development. Proc Natl Acad Sci USA 1997, 94(5):1852-1856

43. Svensson L, Aszodi A, Reinholt FP, Fassler R, Heinegard D, Oldberg A: Fibromodulin-null mice have abnormal collagen fibrils, tissue organization, and altered lumican deposition in tendon. J Biol Chem 1999, 274(14):9636-9647.

44. Vogel KG, Trotter JA: The effect of proteoglycans on the morphology of collagen fibrils formed in vitro. Coll Relat Res 1987, 7(2):105-114.

45. Woo SL: Mechanical properties of tendons and ligaments. I. Quasistatic and nonlinear viscoelastic properties. Biorheology 1982, 19(3):385-396

46. Woo SL, Abramowitch SD, Kilger R, Liang R: Biomechanics of knee ligaments: injury, healing, and repair. J Biomech 2006, 39(1):1-20.

47. Amiel D, Frank C, Harwood F, Fronek J, Akeson W: Tendons and ligaments: a morphological and biochemical comparison. J Orthop Res 1984, 1(3):257-265.

48. Lee J, Harwood FL, Akeson WH, Amiel D: Growth factor expression in healing rabbit medial collateral and anterior cruciate ligaments. lowa Orthop J 1998, 18:19-25.

49. Sciore $P$, Boykiw $R$, Hart DA: Semiquantitative reverse transcriptionpolymerase chain reaction analysis of mRNA for growth factors and growth factor receptors from normal and healing rabbit medial collateral ligament tissue. J Orthop Res 1998, 16(4):429-437.

50. Murray MM, Martin SD, Martin TL, Spector M: Histological changes in the human anterior cruciate ligament after rupture. J Bone Joint Surg Am 2000, 82-A(10):1387-1397

51. Steadman JR, Cameron-Donaldson ML, Briggs KK, Rodkey WG: A minimally invasive technique ("healing response") to treat proximal ACL injuries in skeletally immature athletes. J Knee Surg 2006, 19(1):8-13.

52. Boynton MD, Fadale PD: The basic science of anterior cruciate ligament surgery. Orthop Rev 1993, 22(6):673-679

53. Nagineni CN, Amiel D, Green MH, Berchuck M, Akeson WH: Characterization of the intrinsic properties of the anterior cruciate and medial collateral ligament cells: an in vitro cell culture study. J Orthop Res 1992, 10(4):465-475.

54. Bray RC, Leonard CA, Salo PT: Vascular physiology and long-term healing of partial ligament tears. J Orthop Res 2002, 20(5):984-989.

55. McKean JM, Hsieh AH, Sung KL: Epidermal growth factor differentially affects integrin-mediated adhesion and proliferation of $A C L$ and $M C L$ fibroblasts. Biorheology 2004, 41(2):139-152.

56. Sung KL, Kwan MK, Maldonado F, Akeson WH: Adhesion strength of human ligament fibroblasts. J Biomech Eng 1994, 116(3):237-242.

57. Zhou D, Lee HS, Villarreal F, Teng A, Lu E, Reynolds S, Qin C, Smith J, Sung $\mathrm{KL}$ : Differential MMP-2 activity of ligament cells under mechanical stretch injury: an in vitro study on human $\mathrm{ACL}$ and $\mathrm{MCL}$ fibroblasts. $J$ Orthop Res 2005, 23(4):949-957.

58. O'Donoghue DH, Rockwood CA, Frank GR Jr, Jack SC, Kenyon R: Repair of the anterior cruciate ligament in dogs. J Bone Joint Surg Am 1966, 48(3):503-519.

59. Feagin JA Jr, Curl WW: Isolated tear of the anterior cruciate ligament: 5year follow-up study. Am J Sports Med 1976, 4(3):95-100.

60. Marshall JL, Warren RF, Wickiewicz TL, Reider B: The anterior cruciate ligament: a technique of repair and reconstruction. Clin Orthop Relat Res 1979:97-106.

61. O'Donoghue DH: Treatment of ligament injuries of the knee joint. Wis Med J 1955, 54(12):593-598.

62. O'Donoghue DH, Frank GR, Jeter GL, Johnson W, Zeiders JW, Kenyon R: Repair and reconstruction of the anterior cruciate ligament in dogs. Factors influencing long-term results. J Bone Joint Surg Am 1971, 53(4):710-718

63. Andersson C, Odensten M, Good L, Gillquist J: Surgical or non-surgical treatment of acute rupture of the anterior cruciate ligament. $A$ randomized study with long-term follow-up. J Bone Joint Surg Am 1989, 71(7):965-974

64. Sandberg R, Balkfors B, Nilsson B, Westlin N: Operative versus nonoperative treatment of recent injuries to the ligaments of the knee. $A$ prospective randomized study. J Bone Joint Surg Am 1987, 69(8):1120-1126.

65. Kaplan N, Wickiewicz TL, Warren RF: Primary surgical treatment of anterior cruciate ligament ruptures. A long-term follow-up study. Am J Sports Med 1990, 18(4):354-358.

66. Drogset JO, Grontvedt T, Robak OR, Molster A, Viset AT, Engebretsen L: A sixteen-year follow-up of three operative techniques for the treatment of acute ruptures of the anterior cruciate ligament. J Bone Joint Surg Am 2006, 88(5):944-952.

67. Strand T, Molster A, Hordvik M, Krukhaug Y: Long-term follow-up after primary repair of the anterior cruciate ligament: clinical and radiological evaluation 15-23 years postoperatively. Arch Orthop Trauma Surg 2005, 125(4):217-221.

68. Jones KG: Reconstruction of the anterior cruciate ligament using the central one-third of the patellar ligament. J Bone Joint Surg Am 1970 52(4):838-839.

69. Fetto JF, Marshall JL: The natural history and diagnosis of anterior cruciate ligament insufficiency. Clin Orthop Relat Res 1980:29-38.

70. Hirshman HP, Daniel DM, Miyasaka K: The fate of the unoperated knee ligament injuries. In Knee ligaments: structure, function, injury, and repair Edited by: Daniel DM, Akeson WH, O'Connor JJ. New York: Raven Press; 1990:481-503.

71. Kannus $P$, Jarvinen $M$ : Conservatively treated tears of the anterior cruciate ligament. Long-term results. J Bone Joint Surg Am 1987, 69(7):1007-1012.

72. Noyes FR, Mooar PA, Matthews DS, Butler DL: The symptomatic anterior cruciate-deficient knee. Part I: the long-term functional disability in athletically active individuals. J Bone Joint Surg Am 1983, 65(2):154-162.

73. Beaty J: Knee and leg: soft tissue trauma. In OKU orthopaedic knowledge update Edited by: Arendt EA. Rosemont, IL: American Academy of Orthopaedic Surgeons; 1999. xix, 442

74. Mastrokalos DS, Springer J, Siebold R, Paessler HH: Donor site morbidity and return to the preinjury activity level after anterior cruciate ligament reconstruction using ipsilateral and contralateral patellar tendon autograft: a retrospective, nonrandomized study. Am J Sports Med 2005, 33(1):85-93

75. Aglietti P, Buzzi R, Zaccherotti G, De Biase P: Patellar tendon versus doubled semitendinosus and gracilis tendons for anterior cruciate ligament reconstruction. Am J Sports Med 1994, 22(2):211-217. discussion 217-8

76. Svensson M, Kartus J, Christensen LR, Movin T, Papadogiannakis N, Karlsson J: A long-term serial histological evaluation of the patellar tendon in humans after harvesting its central third. Knee Surg Sports Traumatol Arthrosc 2005, 13(5):398-404

77. Rubinstein RA Jr, Shelbourne KD, VanMeter CD, McCarroll JC, Rettig AC: Isolated autogenous bone-patellar tendon-bone graft site morbidity. Am J Sports Med 1994, 22(3):324-327.

78. Breitfuss $H$, Frohlich R, Povacz P, Resch H, Wicker A: The tendon defect after anterior cruciate ligament reconstruction using the midthird patellar tendon--a problem for the patellofemoral joint? Knee Surg Sports Traumatol Arthrosc 1996, 3(4):194-198.

79. Roe J, Pinczewski LA, Russell VJ, Salmon LJ, Kawamata T, Chew M: A 7-year follow-up of patellar tendon and hamstring tendon grafts for arthroscopic anterior cruciate ligament reconstruction: Differences and similarities. American Journal of Sports Medicine 2005, 33(9):1337-1345.

80. Hertel P, Behrend H, Cierpinski T, MusahI V, Widjaja G: ACL reconstruction using bone-patellar tendon-bone press-fit fixation: 10-Year clinical results. Knee Surgery, Sports Traumatology, Arthroscopy 2005, 13(4):248-255

81. Oiestad BE, Engebretsen L, Storheim K, Risberg MA: Knee osteoarthritis after anterior cruciate ligament injury: a systematic review. Am J Sports Med 2009, 37(7):1434-1443.

82. Ait Si Selmi T, Fithian D, Neyret P: The evolution of osteoarthritis in 103 patients with $A C L$ reconstruction at 17 years follow-up. Knee 2006, 13(5):353-358

83. Kessler MA, Behrend H, Henz S, Stutz G, Rukavina A, Kuster MS: Function, osteoarthritis and activity after ACL-rupture: 11 years follow-up results of conservative versus reconstructive treatment. Knee Surg Sports Traumatol Arthrosc 2008, 16(5):442-448.

84. Liden M, Sernert N, Rostgard-Christensen L, Kartus C, Ejerhed L: Osteoarthritic changes after anterior cruciate ligament reconstruction 
using bone-patellar tendon-bone or hamstring tendon autografts: a retrospective, 7-year radiographic and clinical follow-up study. Arthroscopy 2008, 24(8):899-908

85. Neuman P, Kostogiannis I, Friden T, Roos H, Dahlberg LE, Englund M: Patellofemoral osteoarthritis 15 years after anterior cruciate ligament injury--a prospective cohort study. Osteoarthritis Cartilage 2009, 17(3):284-290.

86. Salmon LJ, Russell VJ, Refshauge K, Kader D, Connolly C, Linklater J, Pinczewski LA: Long-term outcome of endoscopic anterior cruciate ligament reconstruction with patellar tendon autograft: minimum 13year review. Am J Sports Med 2006, 34(5):721-732.

87. von Porat $\mathrm{A}$, Roos $\mathrm{EM}$, Roos $\mathrm{H}$ : High prevalence of osteoarthritis 14 years after an anterior cruciate ligament tear in male soccer players: a study of radiographic and patient relevant outcomes. Ann Rheum Dis 2004, 63(3):269-273

88. Steadman JR, Cameron ML, Briggs KK, Rodkey WG: Healing-response treatment for ACL injuries. Orthopedic Technology Review 2002, 3(3):

89. Gobbi $A$, Bathan $L$, Boldrini L: Primary repair combined with bone marrow stimulation in acute anterior cruciate ligament lesions: results in a group of athletes. Am J Sports Med 2009, 37(3):571-578.

90. Kobayashi K, Healey RM, Sah RL, Clark JJ, Tu BP, Goomer RS, Akeson WH, Moriya $\mathrm{H}$, Amiel D: Novel method for the quantitative assessment of cell migration: a study on the motility of rabbit anterior cruciate $(A C L)$ and medial collateral ligament (MCL) cells. Tissue Eng 2000, 6(1):29-38.

91. Wiig ME, Amiel D, VandeBerg J, Kitabayashi L, Harwood FL, Arfors KE: The early effect of high molecular weight hyaluronan (hyaluronic acid) on anterior cruciate ligament healing: an experimental study in rabbits. J Orthop Res 1990, 8(3):425-434.

92. Murray MM, Spindler KP, Abreu E, Muller JA, Nedder A, Kelly M, Frino J, Zurakowski D, Valenza M, Snyder BD, Connolly SA: Collagen-platelet rich plasma hydrogel enhances primary repair of the porcine anterior cruciate ligament. J Orthop Res 2007, 25(1):81-91.

93. Sakai T, Yasuda K, Tohyama H, Azuma H, Nagumo A, Majima T, Frank CB: Effects of combined administration of transforming growth factorbeta1 and epidermal growth factor on properties of the in situ frozen anterior cruciate ligament in rabbits. J Orthop Res 2002, 20(6):1345-1351.

94. Kobayashi D, Kurosaka M, Yoshiya S, Mizuno K: Effect of basic fibroblast growth factor on the healing of defects in the canine anterior cruciate ligament. Knee Surg Sports Traumatol Arthrosc 1997, 5(3):189-194.

95. Murray MM, Spector M: The migration of cells from the ruptured human anterior cruciate ligament into collagen-glycosaminoglycan regeneration templates in vitro. Biomaterials 2001, 22(17):2393-2402.

96. Meaney Murray M, Rice K, Wright RJ, Spector M: The effect of selected growth factors on human anterior cruciate ligament cell interactions with a three-dimensional collagen-GAG scaffold. J Orthop Res 2003, 21(2):238-244.

97. Kondo E, Yasuda K, Yamanaka M, Minami A, Tohyama H: Effects of administration of exogenous growth factors on biomechanical properties of the elongation-type anterior cruciate ligament injury with partial laceration. Am J Sports Med 2005, 33(2):188-196.

98. Wei XL, Lin L, Hou Y, Fu X, Zhang JY, Mao ZB, Yu CL: Construction of recombinant adenovirus co-expression vector carrying the human transforming growth factor-beta1 and vascular endothelial growth factor genes and its effect on anterior cruciate ligament fibroblasts. Chin Med J (Engl) 2008, 121(15):1426-1432.

99. Spindler KP, Murray MM, Detwiler KB, Tarter JT, Dawson JM, Nanney LB, Davidson JM: The biomechanical response to doses of TGF-beta 2 in the healing rabbit medial collateral ligament. J Orthop Res 2003, 21(2):245-249.

100. Spindler KP, Dawson JM, Stahlman GC, Davidson JM, Nanney LB: Collagen expression and biomechanical response to human recombinant transforming growth factor beta (rhTGF-beta2) in the healing rabbit MCL. J Orthop Res 2002, 20(2):318-324.

101. Hildebrand KA, Woo SL, Smith DW, Allen CR, Deie M, Taylor BJ, Schmidt CC: The effects of platelet-derived growth factor-BB on healing of the rabbit medial collateral ligament. An in vivo study. Am J Sports Med 1998, 26(4):549-554.

102. Murray MM, Spindler KP, Devin C, Snyder BS, Muller J, Takahashi M, Ballard P, Nanney LB, Zurakowski D: Use of a collagen-platelet rich plasma scaffold to stimulate healing of a central defect in the canine ACL. $J$ Orthop Res 2006, 24(4):820-830.
103. Joshi SM, Mastrangelo AN, Magarian EM, Fleming BC, Murray MM: Collagen-platelet composite enhances biomechanical and histologic healing of the porcine anterior cruciate ligament. Am J Sports Med 2009, 37(12):2401-2410.

104. Woo SL, Smith DW, Hildebrand KA, Zeminski JA, Johnson LA: Engineering the healing of the rabbit medial collateral ligament. Med Biol Eng Comput 1998, 36(3):359-364

105. Zhang $Y$, Wang $Y$, Shi B, Cheng $X$ : A platelet-derived growth factor releasing chitosan/coral composite scaffold for periodontal tissue engineering. Biomaterials 2007, 28(8):1515-1522

106. Galiano RD, Tepper OM, Pelo CR, Bhatt KA, Callaghan M, Bastidas N, Bunting S, Steinmetz HG, Gurtner GC: Topical vascular endothelial growth factor accelerates diabetic wound healing through increased angiogenesis and by mobilizing and recruiting bone marrow-derived cells. Am J Pathol 2004, 164(6):1935-1947.

107. Kimura Y, Hokugo A, Takamoto T, Tabata Y, Kurosawa H: Regeneration of anterior cruciate ligament by biodegradable scaffold combined with local controlled release of basic fibroblast growth factor and collagen wrapping. Tissue Eng Part C Methods 2008, 14(1):47-57.

108. Anitua E, Sanchez M, Orive G, Andia I: Delivering growth factors for therapeutics. Trends Pharmacol Sci 2008, 29(1):37-41.

109. Gerich TG, Kang R, Fu FH, Robbins PD, Evans CH: Gene transfer to the rabbit patellar tendon: potential for genetic enhancement of tendon and ligament healing. Gene Ther 1996, 3(12):1089-1093.

110. Pascher A, Steinert AF, Palmer GD, Betz O, Gouze JN, Gouze E, Pilapil C, Ghivizzani SC, Evans CH, Murray MM: Enhanced repair of the anterior cruciate ligament by in situ gene transfer: evaluation in an in vitro model. Mol Ther 2004, 10(2):327-336.

111. Steinert AF, Weber M, Kunz M, Palmer GD, Noth U, Evans CH, Murray MM: In situ IGF-1 gene delivery to cells emerging from the injured anterior cruciate ligament. Biomaterials 2008, 29(7):904-916.

112. Caplan Al: Mesenchymal stem cells. J Orthop Res 1991, 9(5):641-650.

113. Caplan Al: Adult mesenchymal stem cells for tissue engineering versus regenerative medicine. J Cell Physio/ 2007, 213(2):341-347.

114. Watanabe N, Woo SL, Papageorgiou C, Celechovsky C, Takai S: Fate of donor bone marrow cells in medial collateral ligament after simulated autologous transplantation. Microsc Res Tech 2002, 58(1):39-44

115. Young RG, Butler DL, Weber W, Caplan Al, Gordon SL, Fink DJ: Use of mesenchymal stem cells in a collagen matrix for Achilles tendon repair. J Orthop Res 1998, 16(4):406-413.

116. Butler DL, Juncosa-Melvin N, Shearn J, Galloway M, Boivin G, Gooch C: Evaluation of an MSC-based tissue engineered construct to improve patellar tendon repair. Summer Bioengineering Conference; Vail, Colorado 2005.

117. Kanaya A, Deie M, Adachi N, Nishimori M, Yanada S, Ochi M: Intra-articular injection of mesenchymal stromal cells in partially torn anterior cruciate ligaments in a rat model. Arthroscopy 2007, 23(6):610-617.

118. Badylak S, Arnoczky S, Plouhar P, Haut R, Mendenhall V, Clarke R, Horvath $C$ : Naturally occurring extracellular matrix as a scaffold for musculoskeletal repair. Clin Orthop Relat Res 1999:S333-S343.

119. Badylak SF, Park K, Peppas N, McCabe G, Yoder M: Marrow-derived cells populate scaffolds composed of xenogeneic extracellular matrix. Exp Hematol 2001, 29(11):1310-1318.

120. Badylak SF, Tullius R, Kokini K, Shelbourne KD, Klootwyk T, Voytik SL, Kraine $M R$, Simmons C: The use of xenogeneic small intestinal submucosa as a biomaterial for Achilles tendon repair in a dog model. J Biomed Mater Res 1995, 29(8):977-985

121. Dejardin LM, Arnoczky SP, Clarke RB: Use of small intestinal submucosal implants for regeneration of large fascial defects: an experimental study in dogs. J Biomed Mater Res 1999, 46(2):203-211.

122. Dejardin LM, Arnoczky SP, Ewers BJ, Haut RC, Clarke RB: Tissueengineered rotator cuff tendon using porcine small intestine submucosa. Histologic and mechanical evaluation in dogs. Am J Sports Med 2001, 29(2):175-184.

123. Liang R, Woo SL, Nguyen TD, Liu PC, Almarza A: Effects of a bioscaffold on collagen fibrillogenesis in healing medial collateral ligament in rabbits. J Orthop Res 2008, 26(8):1098-1104.

124. Liang R, Woo SL, Takakura Y, Moon DK, Jia F, Abramowitch SD: Long-term effects of porcine small intestine submucosa on the healing of medial collateral ligament: a functional tissue engineering study. J Orthop Res 2006, 24(4):811-819. 
125. Musahl V, Abramowitch SD, Gilbert TW, Tsuda E, Wang JH, Badylak SF, Woo SL: The use of porcine small intestinal submucosa to enhance the healing of the medial collateral ligament--a functional tissue engineering study in rabbits. J Orthop Res 2004, 22(1):214-220.

126. Woo SL-Y, Takakura Y, Liang R: Treatment with bioscaffold enhances the collagen composition and fibril morphology of the healing medial collateral ligament in rabbits. Tissue Eng 2006, 12(1):159-166.

127. Badylak SF, Kochupura PV, Cohen IS, Doronin SV, Saltman AE, Gilbert TW, Kelly DJ, Ignotz RA, Gaudette GR: The use of extracellular matrix as an inductive scaffold for the partial replacement of functional myocardium. Cell Transplant 2006, 15(Suppl 1):S29-S40.

128. Franklin ME Jr, Gonzalez JJ Jr, Glass J J Jr: Use of porcine small intestinal submucosa as a prosthetic device for laparoscopic repair of hernias in contaminated fields: 2-year follow-up. Hernia 2004, 8(3):186-189.

129. Knoll LD: Use of porcine small intestinal submucosal graft in the surgical management of tunical deficiencies with penile prosthetic surgery. Urology 2002, 59(5):758-761.

130. Voytik-Harbin SL, Brightman AO, Kraine MR, Waisner B, Badylak SF: Identification of extractable growth factors from small intestinal submucosa. J Cell Biochem 1997, 67(4):478-491.

131. McDevitt CA, Wildey GM, Cutrone RM: Transforming growth factorbeta1 in a sterilized tissue derived from the pig small intestine submucosa. J Biomed Mater Res A 2003, 67(2):637-640.

132. Karaoglu S, Celik C, Korkusuz P: The effects of bone marrow or periosteum on tendon-to-bone tunnel healing in a rabbit model. Knee Surg Sports Traumatol Arthrosc 2009, 17(2):170-178.

133. Woo SLY, Liang R, Fisher MB: Future of Orthopaedic Sports Medicine and Soft Tissue Healing: The Important Role of Engineering. Cellular and Molecular Bioengineering 2009, 2(3):448-461.

134. Fujie H, Livesay GA, Woo SL, Kashiwaguchi S, Blomstrom G: The use of a universal force-moment sensor to determine in-situ forces in ligaments: a new methodology. J Biomech Eng 1995, 117(1):1-7.

135. Papageorgiou CD, Ma CB, Abramowitch SD, Clineff TD, Woo SL: A multidisciplinary study of the healing of an intraarticular anterior cruciate ligament graft in a goat model. Am J Sports Med 2001, 29(5):620-626.

136. Nirmalanandhan VS, Dressler MR, Shearn JT, Juncosa-Melvin N, Rao M, Gooch C, Bradica G, Butler DL: Mechanical stimulation of tissue engineered tendon constructs: effect of scaffold materials. J Biomech Eng 2007, 129(6):919-923.

137. Checa S, Prendergast PJ: Effect of cell seeding and mechanical loading on vascularization and tissue formation inside a scaffold: A mechanobiological model using a lattice approach to simulate cell activity. $J$ Biomech 2009, 43(5):961-968.

138. Dado D, Levenberg S: Cell-scaffold mechanical interplay within engineered tissue. Semin Cell Dev Biol 2009, 20(6):656-664.

139. Nirmalanandhan VS, Rao M, Shearn JT, Juncosa-Melvin N, Gooch C, Butler $\mathrm{DL}$ : Effect of scaffold material, construct length and mechanical stimulation on the in vitro stiffness of the engineered tendon construct. J Biomech 2008, 41(4):822-828.

140. Phelps CJ, Koike C, Vaught TD, Boone J, Wells KD, Chen SH, Ball S, Specht SM, Polejaeva IA, Monahan JA, Jobst PM, Sharma SB, Lamborn AE, Garst AS, Moore M, Demetris AJ, Rudert WA, Bottino R, Bertera S, Trucco M, Starzl TE, Dai Y, Ayares DL: Production of alpha 1,3-galactosyltransferasedeficient pigs. Science 2003, 299(5605):411-414.

141. McPherson TB, Liang H, Record RD, Badylak SF: Galalpha(1,3)Gal epitope in porcine small intestinal submucosa. Tissue Eng 2000, 6(3):233-239.

142. Wotton FT, Akoh JA: Rejection of Permacol mesh used in abdominal wall repair: a case report. World J Gastroenterol 2009, 15(34):4331-4333.

143. Iannotti JP, Codsi MJ, Kwon YW, Derwin K, Ciccone J, Brems JJ: Porcine small intestine submucosa augmentation of surgical repair of chronic two-tendon rotator cuff tears. A randomized, controlled trial. J Bone Joint Surg Am 2006, 88(6):1238-1244.

144. Sclamberg SG, Tibone JE, Itamura JM, Kasraeian S: Six-month magnetic resonance imaging follow-up of large and massive rotator cuff repairs reinforced with porcine small intestinal submucosa. J Shoulder Elbow Surg 2004, 13(5):538-541.

145. Thomopoulos S, Zampiakis E, Das R, Kim HM, Silva MJ, Havlioglu N, Gelberman RH: Use of a magnesium-based bone adhesive for flexor tendon-to-bone healing. J Hand Surg Am 2009, 34(6):1066-1073.
146. Gulotta LV, Kovacevic D, Ying L, Ehteshami JR, Montgomery S, Rodeo SA: Augmentation of tendon-to-bone healing with a magnesium-based bone adhesive. Am J Sports Med 2008, 36(7):1209-1207.

147. Waselau M, Samii VF, Weisbrode SE, Litsky AS, Bertone AL: Effects of a magnesium adhesive cement on bone stability and healing following a metatarsal osteotomy in horses. Am J Vet Res 2007, 68(4):370-378.

doi: $10.1186 / 1758-2555-2-12$

Cite this article as: $\mathrm{Hsu}$ et al., Functional tissue engineering of ligament healing Sports Medicine, Arthroscopy, Rehabilitation, Therapy \& Technology 2010, 2:12

\section{Submit your next manuscript to BioMed Central} and take full advantage of:

- Convenient online submission

- Thorough peer review

- No space constraints or color figure charges

- Immediate publication on acceptance

- Inclusion in PubMed, CAS, Scopus and Google Scholar

- Research which is freely available for redistribution 